\title{
E-Participation
}

\section{Modeling and Developing with Trust for Decision Making Supplement Purpose}

\author{
Vitri Tundjungsari \\ YARSI University \\ Information Technology Faculty (FTI) \\ J1. Letjen Suprapto, Jakarta Pusat, Indonesia \\ 1(Student of Department of Computer Science and \\ Electronics, Gadjah Mada University)
}

\author{
Jazi Eko Istiyanto, Edi Winarko, Retantyo Wardoyo \\ Department of Computer Science and Electronics \\ Gadjah Mada University \\ Jl. Sekip Utara \\ Yogyakarta, Indonesia
}

\begin{abstract}
ICT has been employed in various areas, including eParticipation to support citizen participation and achieve democracy ideal. Trust as a social behavior can be used as a method to model preferences and facilitate better participation and interaction in a decision making within a group of decision makers. In this paper we present literatures survey related to eParticipation and trust in computer science; we also proposed a Group Decision Support System model and application, which utilizes trust to support decisions in a collaborative team. In brief, the model is based on the synthesis of group members' preferences following an appropriate aggregation procedure.
\end{abstract}

Keywords- e-Participation; trust; group decision making.

\section{INTRODUCTION}

Information and communication technology (ICT) has become deeply involved in various studies regarding decision making. Advances in ICT facilitate solution on some of the decision making problems such as in politics, economics, and engineering sciences. Nowadays, decision making is not only based on single decision maker perspectives but also involves several decision makers, also called as a group decision making. In politics, especially in governmental concept, this group usually consists of government staffs who also expert in their fields. However, government today with democratic concepts requires much more citizen participation in decision making to achieve democracy ideals stated by Abraham Lincoln's (the government of the people, by the people, and for the people). Furthermore, we believe that ICT could be applied to enhance citizen participation in the policy process [36]. Macintosh [22] mentions the overarching objectives of eparticipation are given as: (1) reach a wider audience to enable broader participation; (2) support participation through a range of technologies to cater for the diverse technical and communicative skills of citizens; (3) provide relevant information in a format that is both more accessible and more understandable to the target audience to enable more informed contributions; (4) engage with a wider audience to enable deeper contributions and support deliberative debate.

There is no clear definition of e-Participation from various literatures, however we can conclude that ICT usage (particularly Internet based) in those participation action and mechanisms, with the implication that the technology has the ability to change or transform the communication processes between the participants involving citizens in societal decision making, is also called as e-Participation. It is normally associated with some form of political deliberation or decision-making within the formal political process (e.g. voting), or outside it (e.g. political activism) [30].

Our literatures review concentrates on how participatory research can be applied in the decision-making sense, and also includes e-Participation research's state of the art. Moreover, this paper contributes to the work of defining the emerging research area of e-Participation by: (1) describing and categorizing recent set of relevant and important literatures in area of e-Participation; (2) proposing new model of eParticipation for decision making purpose and developing it into a prototype called Par-GDSS.

The rest of the paper is organized as follows. Section 2 provides a brief review of existing e-Participation research. Section 3 and 4 presents our e-Participation model and application. Finally in section 5 we conclude the paper and state our future work.

\section{E-PARTICIPATION LITERATURES SURVEY}

E-Participation is a technology-mediated interaction between the civil society sphere and the formal politics sphere, and between the civil society sphere and the administration sphere [30]. The main point of e-Participation is the citizen, i.e., the purpose of e-Participation is to increase citizens' abilities to participate in digital governance, including participation in the political process and the transformation of digital government information and services.

Literatures survey shows that e-Participation is an emerging research area and has been studied and implemented in some developed and developing countries ([11], [26], [30]). However, survey also finds out that e-Participation (related to Decision making) still has limited source both in theory development and its practice. In table 1 , we present eParticipation research based on its motivation and reference discipline from 29 paper sources. 
E-PARTICIPATION ClassifiCATION BASED ON RESEARCH MotiVATION

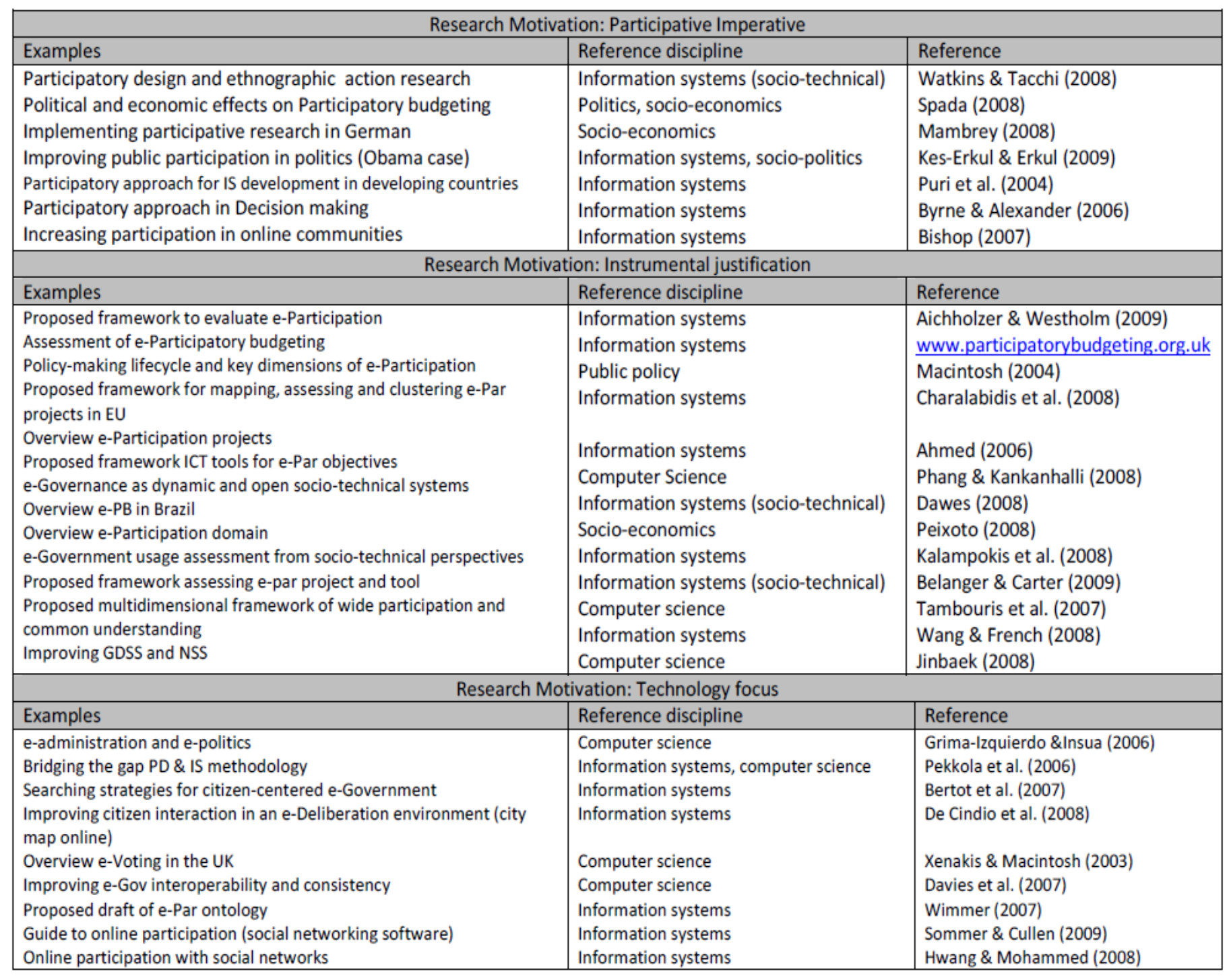

Sanford and Rose [30] categorize e-Participation motivation into:

1. The participative imperative. This motivation emphasize in participation principle where stakeholders in society (citizens in various roles and stakeholder groupings) have an intrinsic right to participate in the formation and execution of public policy, especially when it involves their interests. This principle is derived by argumentation from principles in philosophy and political science, and is commonly protected in democratic societies by law, convention, and practice. However, the extent of this intrinsic right, the nature of the participation, and the democratic forms which enable it are open to debate. This research motivation can therefore be associated with a desire to understand, improve or reshape societal participation forms.

2. Instrumental justification. This motivation relate to the study of the effectiveness of government and policy making is, and how to improve it. Stakeholder participation in public affairs can be instrumental in more effective policy making and governance. This is because consultation with societal stakeholders can lead to improved public policies and encourage adoption and implementation of policy and services.

3. Technology focus. This motivation point out the role, effectiveness of information and communications technology to improve participation in the political process through: enhanced reach and range (inclusion); increased storage, analysis, presentation, and dissemination of contributions to the public policy and service debate; better management of scale; and by improvements to the process of organizing the public sphere debate.

However in practical implementation, those motivations often overlap with each other's, thus we present only the dominant motivation of the research paper as described in table 1 . 
In reference discipline related to e-Participation, Sanford and Rose [30] identify several related fields, i.e.: (1) information systems, (2) political science, (3) social and political philosophy, (4) social and economic philosophy, (5) public policy, (6) computer science. Further explanation of eParticipation can be found in [30]; [22]; [34]; [44]; [28]; [17].

Phang and Kankanhalli [28] in their paper stated that eParticipation initiatives have several objectives, such as: to provide citizens information, to support citizens' participation, to utilise citizen's input in decision making processes, and to investigate citizens' needs. Table 4 shows e-Participation initiatives categorization based on its objectives, i.e.: (1) information exchange, (2) education and support-building, (3) decision-making supplement, and (4) input probing. Our work focuses on how technology can support decision making processes as an e-Participation objective.

Although Non-government organization (NGO) and private sector are also relevant to e-Participation but basically e-Participation is a citizen focused research. Macintosh [22] has identified e-Participation as part of e-Democracy. EDemocracy is defined as ICT usage involving citizens, in order to support a democratic decision making process and to strengthen a representative democracy.

A democratic decision making process is divided into two categories, which are: e-Voting and e-Participation (Macintosh, 2004). Therefore, it can be concluded that technology involved in e-Participation should deliberate citizens' opinion, reform government's citizen and furthermore provide better government's service to its citizens.

In spite of several pro and contras regarding the prospects of ICT towards better governance and democracy, this paper believes that ICT can facilitate participation in decision making processes and also supports collective deliberation.

\section{Proposed E-PARTICIPATION MODEL}

As stated above, the main objective of this study is to support and facilitate wider participation using ICT (eParticipation) as decision-making supplement. For this reason, we propose a model utilize multi-criteria decision analysis (MCDA) aiming to assist decision makers on the entire process following a structured approach (specifically in process 1, figure 1); trust and reputation mechanisms to encourage and assist in knowledge sharing and education process (process 2, figure 1) also group decision making process (process 3, figure 1); and consensus with centrality approach to construct group decision (process 3, figure 1).

Moreover, the model consists of three main processes (figure 1), i.e. [38]:

1. Agenda setting process. This process mainly contains of clarification of the decision context, i.e.: problem and objective definition, criteria and alternatives exploration, and identification of participants.

2. Knowledge sharing and education process. This process involves iterative learning process by providing advice taking service. A decision maker can find and ask advisors using trust and reputation mechanisms, in order to improve her decision's quality. This process also aim to inform participants about the why and how decision is made from other participants' (e.g. experts) perspectives.

3. Group decision making process. This process includes evaluation of decision criteria and alternatives. All alternatives are measured with regard to every decision criterion using a related measurement scale. These evaluations based on subjective judgments by participants themselves. This process also supports participants' decisions iteration and refinement in order to reach consensus, facilitating by supra decision maker role.

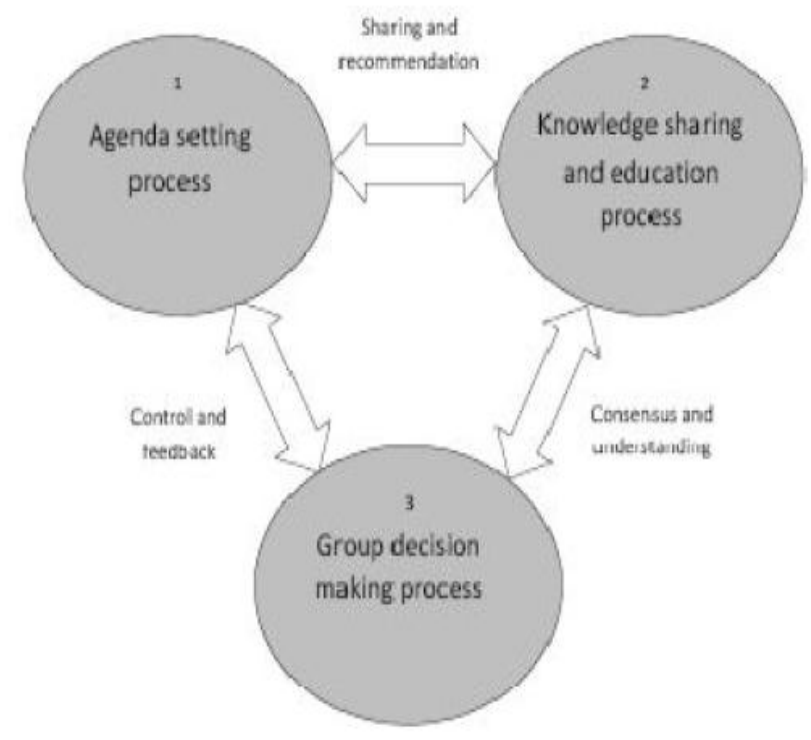

Figure 1. The Proposed Model

Related to computer science, trust has been used in various fields, e.g. data/information filtering and collecting strategy [21], [13], [39], [40]; security mechanism [35], [6]; information/ knowledge sharing [19], [4]; and recommender system [42], [24], [46], [32]. Table 2 summarizes several literatures in trust related to computer science application.

As we can see from table 2, trust model has not been utilized in decision making area; while it has been used widely in data/ information collecting and filtering and recommender systems. Our effort is employed trust into our e-Participation development. Reputation and recommendation are the common terminologies used in trust model. Further explanation of how our trust model works within our decision making model can be found in [37] and [38].

For implementing our model into Par-GDSS application, we follow framework of ICT exploitation for e-Participation initiatives described by Phang and Kankanhalli [28]. The framework in table 4 shows there is no single participatory technique and ICT tool that can satisfy all four objectives of eParticipation initiatives. Therefore it is important to first identify the objective to be served by the initiative to improve the probability of success of an e-Participation initiative, 
followed by a careful selection of the best-matching techniques and ICT tools for the objective [28].

TRUST MODEL AND APPLICATION USED IN COMPUTER SCIENCE

\begin{tabular}{|c|c|c|c|c|c|}
\hline \multirow[b]{2}{*}{ Aplication } & \multicolumn{3}{|c|}{ Used terminology } & \multirow[b]{2}{*}{ Environment } & \multirow[b]{2}{*}{ Author } \\
\hline & Reputation & Recommendation & Others & & \\
\hline $\begin{array}{l}\text { Datal } \\
\text { Information } \\
\text { collecting and } \\
\text { filtering }\end{array}$ & $\begin{array}{l}\text { No } \\
\text { Yes } \\
\text { No } \\
\text { No } \\
\text { No }\end{array}$ & $\begin{array}{l}\text { Yes } \\
\text { Yes } \\
\text { Yes } \\
\text { Yes } \\
\text { Yes }\end{array}$ & $\begin{array}{l}\text { No } \\
\text { No } \\
\text { No } \\
\text { No } \\
\text { No }\end{array}$ & $\begin{array}{l}\text { decentralized } \\
\text { networks } \\
\text { distributed } \\
\text { systems } \\
\text { distributed } \\
\text { systems } \\
\text { social networks } \\
\text { distributed } \\
\text { systems }\end{array}$ & $\begin{array}{l}\text { Lin et al. (2007) } \\
\text { Umuhoza et al. (2008) } \\
\text { O'Donovan \& Smyth } \\
\text { (2008) } \\
\text { Walter et al. (2007) } \\
\text { Lifen (2008) }\end{array}$ \\
\hline $\begin{array}{l}\text { Security } \\
\text { mechanisms }\end{array}$ & $\begin{array}{l}\text { Yes } \\
\text { Yes }\end{array}$ & $\begin{array}{l}\text { No } \\
\text { Yes }\end{array}$ & $\begin{array}{l}\text { penalty } \\
\text { evaluation } \\
\text { No } \\
\end{array}$ & $\begin{array}{l}\text { P2P networks } \\
\text { grid environment }\end{array}$ & $\begin{array}{l}\text { Tian et al. (2006) } \\
\text { Bhanwar \& Bawa } \\
(2009)\end{array}$ \\
\hline $\begin{array}{l}\text { Information/ } \\
\text { knowledge } \\
\text { sharing }\end{array}$ & $\begin{array}{l}\text { Yes } \\
\text { No }\end{array}$ & $\begin{array}{l}\text { No } \\
\text { No }\end{array}$ & $\begin{array}{l}\text { risk } \\
\text { evaluation } \\
\text { No }\end{array}$ & $\begin{array}{l}\text { P2P networks } \\
\text { web-based }\end{array}$ & $\begin{array}{l}\text { Liang \& Shi (2007) } \\
\text { Bencina (2007) }\end{array}$ \\
\hline $\begin{array}{l}\text { Recommender } \\
\text { systems }\end{array}$ & $\begin{array}{l}\text { Yes } \\
\text { No } \\
\text { No } \\
\text { No }\end{array}$ & $\begin{array}{l}\text { Yes } \\
\text { Yes } \\
\text { Yes } \\
\text { Yes }\end{array}$ & $\begin{array}{l}\text { No } \\
\text { No } \\
\text { No } \\
\text { No }\end{array}$ & $\begin{array}{l}\text { P2P networks } \\
\text { distributed } \\
\text { systems } \\
\text { ubiquitous } \\
\text { environment } \\
\text { P2P networks }\end{array}$ & $\begin{array}{l}\text { Wang \& Vassileva } \\
(2003) \\
\text { Montaner et al. (2002) } \\
\text { Yuan et al. (2006) } \\
\text { Song et al. (2004) }\end{array}$ \\
\hline
\end{tabular}

Our paper is oriented toward e-Participation efforts with the decision-making supplement objective aim to extract specific information from citizens, such as, citizens' preferences on the use of an empty plot of land in the city. In these e-Participation efforts, citizens are given an opportunity for direct input into the planning process, as mentioned by Phang and Kankanhalli (2008).

Therefore our model provides characteristics, which are: control of participation processes, interactions among planners and participants, mechanisms for data collection. Those characteristics aim to support decision-making supplement as e-Participation objectives.

Related to our e-Participation application (namely as ParGDSS), we construct and integrate trust model into our proposed decision making model. Table 3 describes trust properties in our model and application. The user as actors in the model consists of four different level, categorized by its trust level (tl) which are:

- $\quad$ Citizen with trust level=1;
- $\quad$ Citizen with trust level=2;

- $\quad$ Citizen with trust level=3;

- $\quad$ Citizen with trust level=4.

TRUST Properties WITHIN THE PROPOSED MODEL

\begin{tabular}{|c|c|c|}
\hline User/Actor & Trust Properties & Environment \\
\hline $\begin{array}{l}\text { Citizen, i.e.: } \\
\text { - Regular citizen } \\
(\mathrm{tl}=1 \text { dan } \mathrm{tl}=2) \\
\text { - Expert citizen } \\
(\mathrm{tl}=3 \text { dan } \mathrm{tl}=4)\end{array}$ & $\begin{array}{l}\text { - Always between two entities (Trustee dan Truster) } \\
\text { - Non-symmetrical (e.g.: if A trust B, then doesn't mean B } \\
\text { trust A) } \\
\text { - Conditionally transitive (e.g.: if A trust B, B trust C, } \\
\text { then A trust C under condition that B as a recommender } \\
\text { to C, based on C's reputation). } \\
\text { - Context-based (a trustee only can be trusted in one/ } \\
\text { several specific categories) } \\
\text { - Reflexively (a truster has to trust system and his/ her } \\
\text { own judgment to determine trustee's trust value) } \\
\text { - Dynamically (trust value is dynamically changed). }\end{array}$ & $\begin{array}{l}\frac{\text { Trust }}{\text { - Decentral }} \\
\text { peer } \\
\text { - Partial trust } \\
\text { algorithm }\end{array}$ \\
\hline
\end{tabular}

Environment in this trust model consists of decentral peer and partial trust algorithm. Decentral Peer in this model works for all of the peers within the network can act as end-peer or recommender for other peers.

This is a simple but the least reliable model since there is no need for any recommenders in the system to prove the recognition of its recommendation. While partial trust algorithm applies when a peer uses only some of the recommendations to measure trust value of another peer [25].

For the next step, we then implement our model into an application named Par-GDSS. Par-GDSS is a web based application which can be reached online at www.pargdss.com. We follow a three-step procedure proposed by Phang and Kankanhalli [28] as presented in figure 2.

We define Par-GDSS objective as a decision-making supplement. The participatory technique used is group decision making with consensus achievement. Consensus achievement is produced by the role of Supra decision maker as the leader of the group.

Finally, we then decide Group Decision Support Systems (GDSS) with trust and reputation mechanisms as the ICT tool to support the technique and, in turn, the objective.

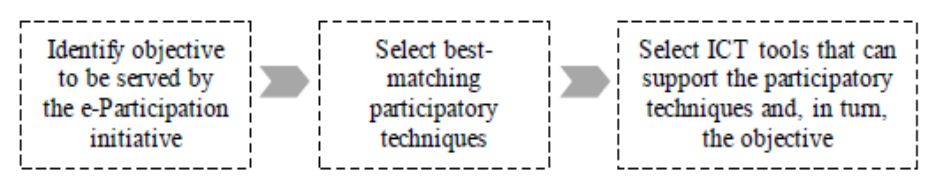

Figure 2. A three-step procedure to implement e-Participation [28] 
TABLE I. A FRAMEWORK OF ICT EXPLOITATION FOR ICT INITIATIVES [28]

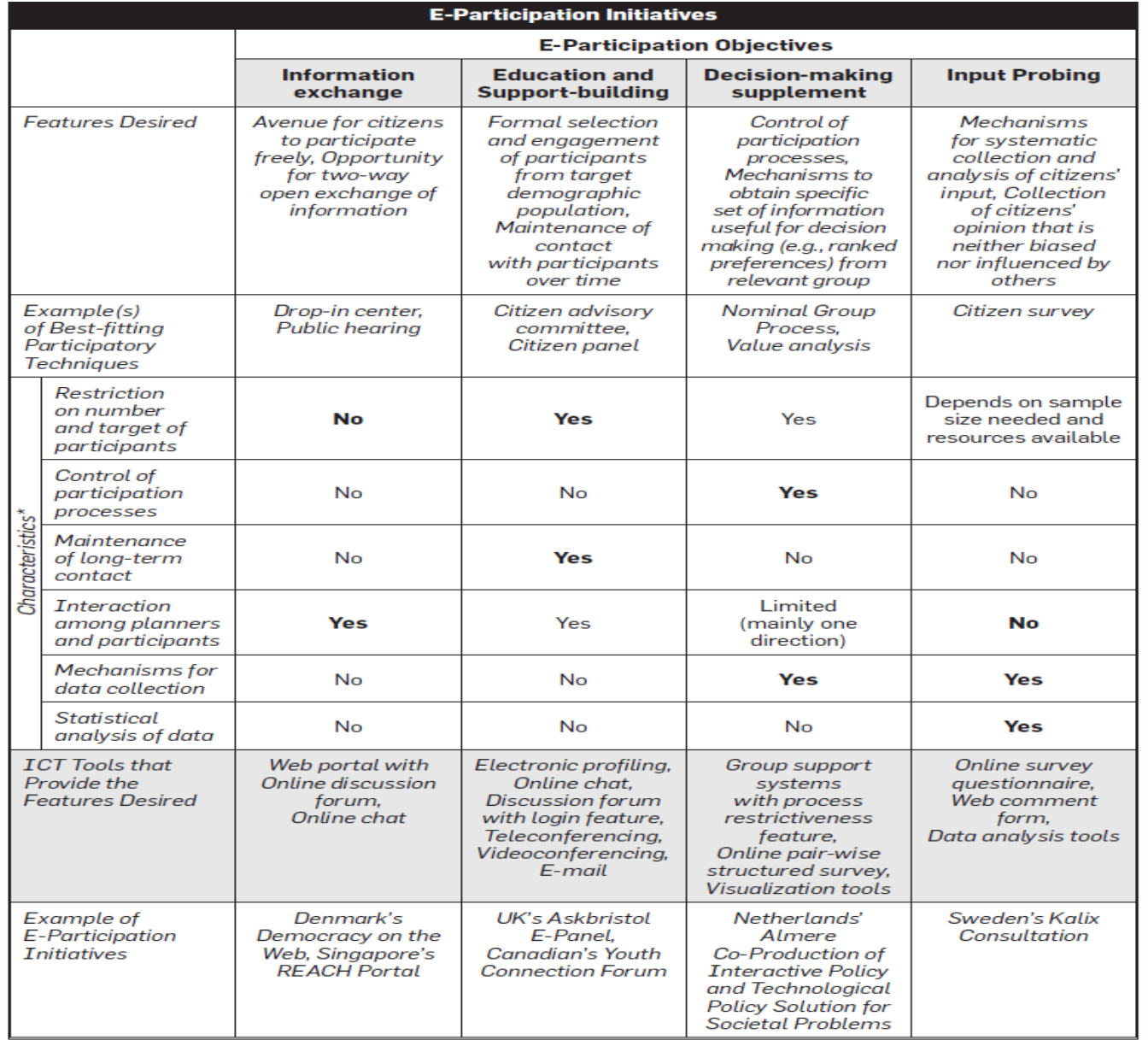

\section{PAR-GDSS: E-PARTICIPATION APPLICATION}

The architecture of the GDSS (named as Par-GDSS) employs M (Model), V (View), C (Controller) design pattern, which adopted from software engineering approach. MVC separates web application's logic from layer presentation so then it has components to manipulate data, user interface, and application control.

Figure 2 describes the systems architecture of Par-GDSS. At the user side, there are many functionality elements (such as: create account, view event, etc) that could be done by user/ citizen with various role, i.e.: (admin, citizen with $\mathrm{tl}=1$, citizen with $\mathrm{tl}=2$, citizen with $\mathrm{tl}=3$, citizen with $\mathrm{tl}=4$ ).

There are several modules have been developed for ParGDSS, i.e.:

- $\quad$ Citizen: This module handles all requests related with (1) retrieve, add, delete, update Citizen;

(2) trust and reputation mechanisms and theirs calculation.

- Event: This module handles all requests related with (1) retrieve, add, delete, update Event;

(2) individual decision;

(3) trust and reputation mechanisms and theirs calculation;
(4) document and information related with an Event;

(5) control and feedback mechanisms.

- Dashboard: This module handles all information related with an event involving a citizen (user), e.g.: received message (inbox), newest comment, and upload document.

- Modul Forum: This module handles all activities related with Discussion Forum, e.g.: post topic, post thread, post discussion, view discusssion.

- Modul Message: This module handles all activities related with sending and receiving messages between users (one to one user).

- Modul Session: This module handles user session.

Par-GDSS is a web based application which can be accessed through a login page, where users have to provide appropriate password. The system recognizes two roles: Supra decision maker and citizen.

Supra decision maker works on a fully functional mode of the system, while citizen work on a mode presenting a subset of functionality based on their trust level. Figure 3 shows the functionality for each citizen. 

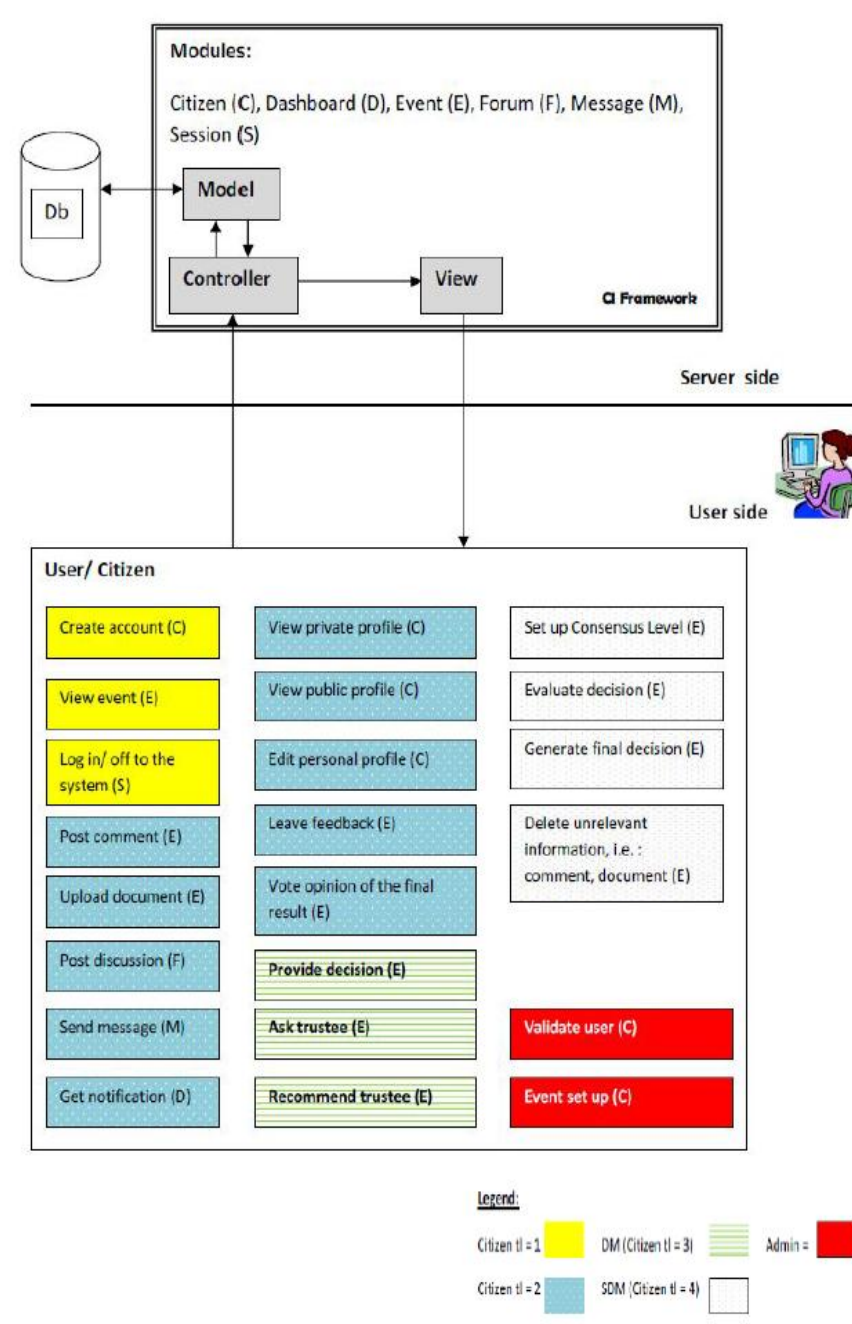

Figure 3. Par-GDSS Overall Architecture

Figure 4 shows the beginning of the systems, i.e. login to system, until the end of the system, i.e. view the result and provide feedback. The event in Par-GDSS changes several times related to the decision making progress, which consists of:

- Discussed event: this feature is model's interpretation of Agenda Setting process.

- Ongoing event: this feature is model's interpretation of Knowledge Sharing and Education process.

- Resolved event: this feature is model's interpretation of Group Decision Making process.

For every event changes, we provide two kinds of mechanisms, i.e.: trust and reputation mechanisms, consensus achievement mechanism.

\section{CONCLUSION}

Our literatures survey finds that e-Participation in decision making area is still lack of research and implementation. Therefore, this paper proposes an e-Participation model using trust to assist participatory decision making, while enhances collective deliberation among citizens. The idea of trust mechanism utilization is coming from the possibility of any doubtful has been taken by decision maker. Unlike expert decision makers, citizens as decision makers could have no prior information regarding what and how decision should be made of.

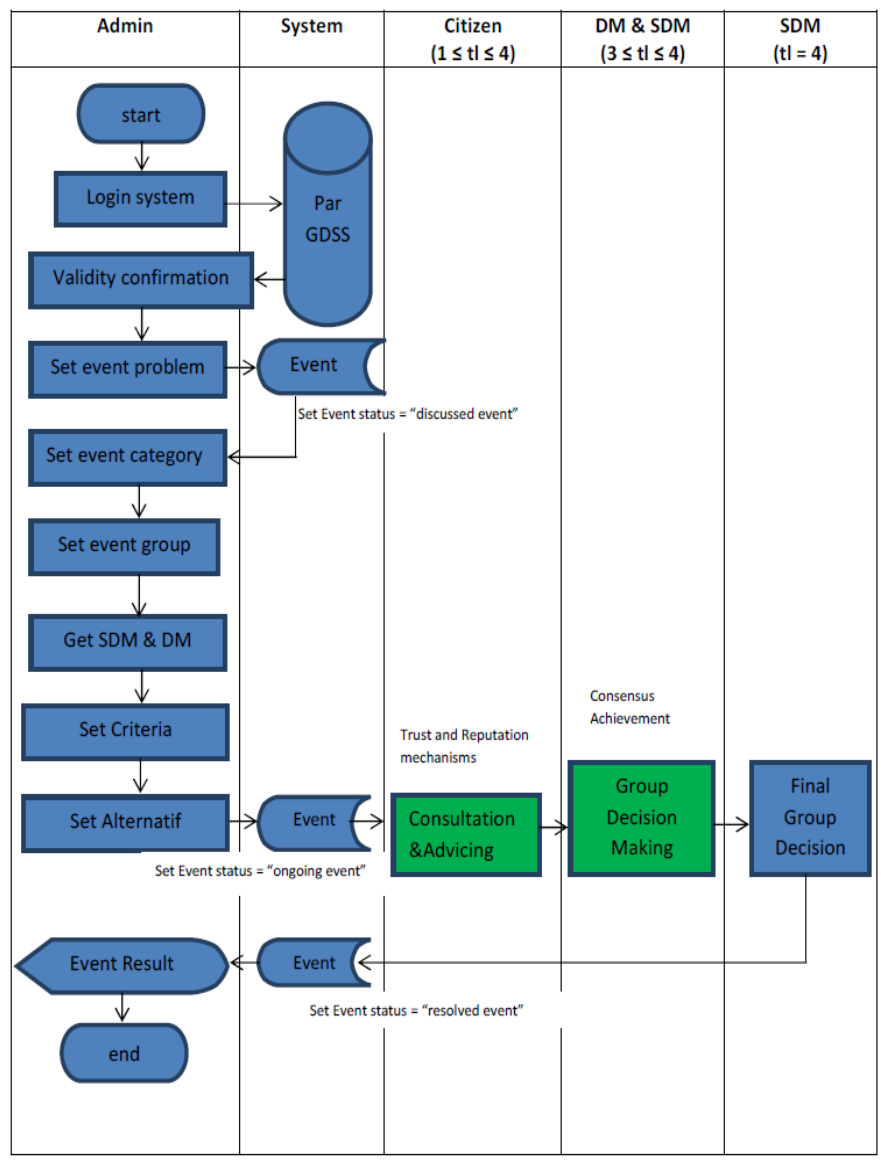

Figure 4. Par-GDSS Features and Activities Diagram

This paper then proposes to adopt the 'real life' behavior, by providing interaction and consultation between citizens in order to produce better decision's quality. Focusing on the process of making decisions on public matters with citizen participation, this paper also investigates state-of-the art researches related to e-Participation.

The advantages of our proposed approach are:

(1) it provides a transparent control mechanisms by employing trust and reputation mechanisms, so that it can promote democracy aspects and not only works as group decision support systems,

(2) it can support various decision makers with different backgrounds and skills by providing information and knowledge through trust and reputation mechanisms (a beginner decision maker can learn how to decide from other trusted and recommended sources),

(3) it can enhance participation level to some extent by providing wider participation access and resources and also supports better interaction among decision maker (learning and sharing process to achieve final group decision). Our 
future works will be concentrated on our proposed model testing and evaluation.

\section{REFERENCES}

[1] N. Ahmed, An Overview of e-Participation Models, "United Nations Report (Division for Public Administration and Development Management DPADM/ Department of Economic and Social Affairs UNDESA)", April 2006.

[2] G. Aichholzer, H. Westholm, "Evaluating eParticipation Projects: Practical Examples and Outline of an Evaluation Framework", European Journal of ePractice, www.epracticejournal.eu, vol. 1(7), March 2009.

[3] F. Belanger, L. Carter, "The Impact of The Digital Divide on eGovernment Use", Communications of The ACM, vol. 52 (4), April 2009, pp. 132-135.

[4] J. Bencina, "Web-based Decision Support System for the Public Sector Comprising Linguistic Variables", Informatica, vol. 31, 2007, pp. 311323.

[5] J.C. Bertot, P.T. Jaeger, C.R. McClure, "Citizen-centered E-Government Services: Benefits, Costs, and Research Needs", Proceeding of the 9th Annual International Digital Government Research Conference 2008, 2008, pp. 137-141.

[6] S. Bhanwar, S. Bawa, "Establishing and Evaluating Trust in a Grid Environment", in $10^{\text {th }}$ International Symposium on Pervasive Systems, Algorithms, and Networks, Kaohsiung, Taiwan, December 14-16, 2009.

[7] J. Bishop, 2007, "Increasing participation in online communities: A framework for human-computer Interaction", Journal of Computers in Human Behavior, vol. 23(4), July 2007, pp. 1881-1893.

[8] E. Byrne, P.M. Alexander, "Questions of Ethics: Participatory Information Systems Research in Community Settings", Proceedings of SAICSIT 2006 PDC 2006 - the ninth Participatory Design Conference 2006, Trento, Italy, 1-5 August, 2006, pp. 117-126.

[9] Y. Charalabidis, L. Kipenis, S. Koussouris, J. Psarras, "Multi-faceted Analysis of Electronic Participation Projects at European Level: A Systemic Approach", www.ep-momentum.eu, accessed on 12 Oktober 2009.

[10] J. Davies, T. Janowski, A. Ojo, "Technological Foundations of Electronic Governance", Proceedings of International Conference on Theory and Practice of Electronic Government (ICEGOV) 2007, Macao, December 10-13, 2007, pp. 5-11.

[11] S.S. Dawes, "Governance in the information age: a research framework for an uncertain future", Proceedings of the 9th Annual International Digital Government Research Conference, Montreal, Canada, May 18, 2008, pp. 290-297.

[12] F. De Cindio, C. Peraboni, L. Sonnante, "Improving citizens' interactions in an e-deliberation Environment", Proceedings of Advances Visual Interfaces (AVI) 08, Napoli, Italy, May 28-30, 2008, pp. 486-487, ACM Digital Library.

[13] J. Donovan, B. Smyth, "Trust No One: Evaluating Trust-based Filtering for Recommenders", Proceedings of the 19th International Joint Conference on Artificial Intelligence IJCAI, 2005.

[14] C. Grima-Izquierdo, D. Rios Insua, "Designing a General Architecture to Support eGovernment", http://www.publicsphereproject.org/events/diac08/proceedings/10.eGove rnment Architecture.Grima-Izquierdo_and_Rios_Insua.pdf, 2006, accessed on 8 Desember 2009.

[15] J. Hwang, A.B. Mohammed, "Approaching e-democracy: A Case Study Analysis from Jordan", Proceedings of the 3rd 2008 International Conference on Convergence and Hybrid Information Technology, 2008.

[16] K. Jinbaek, "A Model and Case for Supporting Participatory Public Decision Making in e-Democracy", Journal of Group Decision Negotiation, vol. 17, pp. 179-193, May 2008, Springer Science \& Business Media B.V.

[17] E. Kalampokis, E. Tambouris, K. Tarabanis, "A Domain Model for eParticipation", Proceedings of The Third International Conference on Internet and Web Applications and Services (ICIW), Athens, Greece, June 8-13, 2008, pp, 25-30, IEEE Digital Library.

[18] Kes-Erkul, R.E. Erkul, "Web 2.0 in the Process of e-participation: The Case of Organizing for America and the Obama Administration", US
NCDG (National Center for Digital Government) 2009 Working Paper No. 09-001, 2009.

[19] Z. Liang, L. Shi, "PET: A Personalized Trust Model with Reputation and Risk Evaluation for P2P Resource Sharing", Proceedings the $38^{\text {th }}$ Annual Hawaii International Conference on System Sciences, January 03-06, 2005.

[20] L. Lifen, "Trust Derivation and Transitivity in a Recommendation Trust Model", Proceedings in International Conference on Computer Science and Software Engineering, 2008.

[21] Z. Lin, X. Feng, W. Yuan, L. Jian, "A Semantic and Time Related Recommendation-Feedback Trust Model", Proceedings of Second International Conference on Availaibility, Reliability, and Security (ARES 2007), Vienna, Austria, April 10-13, 2007, pp. 765-774, IEEE Digital Library.

[22] A. Macintosh, "Characterizing E-Participation in Policy-Making", Proceedings of the 37th Hawaii International Conference on System Sciences - 2004 Track 5, Hawaii USA, January 5-8, 2004, pp. 1-10.

[23] P. Mambrey, "From Participation to e-Participation: The German Case", Proceedings of the $2^{\text {nd }}$ International Conference on Theory and Practice of Electronic Government (ICEGOV2008), Cairo, Egypt, December 1-4, 2008, pp. 355-360.

[24] M. Montaner, B. L'opez, B., J.L. de la Rosa, "Opinion-based Filtering through Trust", Proceedings of CIA'02 LNAI 2446, 2002, pp. 164-178.

[25] I. Nurtanti, "Trust Algorithm in Files Sharing P2P Network", Master Thesis, Faculty of System Engineering, Policy Analysis and Management, Delft University of Technology, Delft, the Netherlands, 2008.

[26] T. Peixoto, "e-Participatory Budgeting: e-Democracy from theory to success'”, e-Working Papers 2008, e-Democracy Centre, Universität Zürich, p. 4.4 Available at http://www.edemocracycentre.ch/files/Tiago.pdf , accessed on January 19, 2009.

[27] S. Pekkola, N. Kaarilahti, P. Pohjola, "Towards Formalised End-User Participation in Information Systems Development Process: Bridging the Gap between Participatory Design and ISD Methodologies", Proceedings Participatory Design Conference, vol. 1, Trento, Italy, August 1-5, 2006, pp. 21-30.

[28] C.W. Phang, A. Kankanhalli, "A Framework of ICT Exploitation for EParticipation Initiatives", Communications of the ACM, December 2008, 51(12), pp. 128-132.

[29] S.K. Puri, E. Byrne, J. Nhampossa, Z.B. Leopoldo, Quraishi, "Contextuality of Participation in IS Design: A Developing Country Perspective", Proceedings of the 8th Participatory Design Conference 2004, vol. 1, Toronto, Canada, July 27-31, 2004, pp. 42-52, ACM Digital Library.

[30] C.Sanford, J. Rose, J., "Characterizing eParticipation", International Journal of Information Management, vol. 27(6), 2007, pp. 406-421.

[31] L. Sommer, R. Cullen, "Participation 2.0: a Case Study of eParticipation within the New Zealand Government", Proceedings of the 42nd Hawaii International Conference on System Sciences - 2009, Hawaii, USA, January 5-8, 2009.

[32] W. Song, V.V. Phoha, X. Xin, "An Adaptive Recommendation Trust Model in Multiagent System", Proceedings of the IEEE/WIC/ACM International Conference on Intelligent Agent Technology (IAT'04), 2004.

[33] P. Spada, "The Economic and Political Effects of Participatory Budgeting", Yale University, 2009.

[34] E. Tambouris, N. Liotas, K. Tarabanis, "A Framework for Assessing eParticipation Projects and Tools", Proceedings of the 40th Hawaii International Conference on System Sciences, Hawaii, USA, January 36, 2007, pp. 1-10.

[35] C.Tian, S. Zhou, W. Wang, S. Cheng, "An Efficient Attack-Resistant Trust Model for P2P Networks", International Journal of Computer Science and Network Security, vol. 6(11), 2006.

[36] V. Tundjungsari, J.E. Istiyanto, P. Santoso, "Building Public Trust through Public Participation Using e-Governance", Proceedings of Rural International Conference on ICT, 2009, ITB, Bandung, Indonesia, June 17-18, 2009, pp. 155-162.

[37] V. Tundjungsari, J.E. Istiyanto, E. Winarko, R. Wardoyo, "A Trust based Reputation Model to Seek Judgment and Advice in Participatory Decision Making", Proceedings of the $2^{\text {nd }}$ International Conference on Distributed Framework and Application (DfMA), Yogyakarta, Indonesia, August 2-3, 2010, IEEE Digital Library. 
[38] V. Tundjungsari, J.E. Istiyanto, E. Winarko, R. Wardoyo, "Enhancing Participation Process in Public Decision Making with MCDA and Trust Modeling", International Journal of Computer Science Issues, Vol. 8, Issue 1, January 2011.

[39] D. Umuhoza, J.I. Agbinya, D. Moodley, A. Vahed, "A Reputation based Trust Model for Geospatial Web Services", Proceedings of $1^{\text {st }}$ WSEAS International Conference on Environmental and Geological Science and Engineering (EG'08), Malta, September 11-13, 2008, http://ict4eo.meraka.csir.co.za/ict4eo/publications-and-researchoutcomes/documents/A_reputationbased_trustModel_for_Geospatial_W ebServices.pdf.

[40] F.E. Walter, S. Battiston, F. Schweitzer, "A Model of a Trust-based Recommendation System on a Social Network", Journal of Autonomous Agents and Multi-Agent Systems, vol.16(1), 2007, pp.57-74.

[41] W. Wang, S. French, "A Multi-Dimensional Framework for Facilitating Wide Participation and Common Understanding", Proceedings of WebScience'08, Pittsburgh, Pennsylvania, USA, June 19, 2008, http://users.ecs.soton.ac.uk/dem/workshops/webscience08/papers/websci 07-wang.pdf.
[42] Y. Wang, J. Vassileva, "Trust and Reputation Model in Peer-to-Peer Networks", Proceedings of the $3^{\text {rd }}$ International Conference on Peer-toPeer Computing, 2003, p.150.

[43] J. Watkins, J.A. Tacchi, "ICT for Creative Engagement : Participatory Design and Ethnographic Action Research". In: HCI for Community and International Development Workshop, Florence, Italy, 5-6 April 2008, http://eprints.qut.edu.au/17933/1/c17933.pdf.

[44] M.A. Wimmer, "Ontology for an e-Participation Virtual Resource Centre", Proceedings of the $1^{\text {st }}$ International Conference on Theory and Practice of Electronic Government (ICEGOV2007), Macao, December 10-13, 2007, pp. 89-98.

[45] A. Xenakis, A. Macintosh, "E-electoral Administration: Organizational Lessons Learned from the Deployment of E-voting in the UK", Proceedings of the 2005 National Conference on Digital Government Research (dg.O), vol.89, Atlanta, Georgia USA, May 15-18, 2005, pp. 191-197.

[46] W. Yuan, D. Guan, S. Lee, Y. Lee., A. Gavrilov, "Finding Realiable Recommendations for Trust Model", Lecture Notes in Computer Science, vol. 4255, 2006, pp. 375-386, Springer-Verlag Publisher.

[47] www.participatorybudgeting.org,uk, accessed on 12 October 2009. 